\title{
FAKTOR - FAKTOR YANG MEMPENGARUHI RETURN SAHAM PADA PERUSAHAAN LQ-45 TERDAFTAR DI BEI TAHUN 2016-2017
}

\author{
Oleh: Syahna Rizky Utaminisa \\ syahna66@gmail.com \\ (Program Studi Akuntansi, FE Universitas Islam Batik Surakarta)
}

\begin{abstract}
Abstrak-Penelitian ini bertujuan untuk mengetahui pengaruh Return on Asset (ROA), Earning Per Share (EPS), Return On Equity (ROE), dan Debt to Equity Ratio (DER) terhadap return saham pada perusahaan LQ-45 yan terdaftar di BEI tahun 2016-2017. Populasi dalam penelitian ini berjumlah 70 perusahaan. Teknik penentuan sampel menggunakan teknik purposive sampling, sehingga sampel akhir yang didapatkan adalah 55 perusahaan. Data yang digunakan adalah data sekunder yang diperoleh dari data laporan keuangan indeks LQ-45 yang terdaftar di BEI. Metode penelitian yang digunakan adalah uji asumsi klasik dan analisis regresi linear berganda dengan bantuan aplikasi SPSS versi 21. Berdasarkan hasil penelitian menunjukkan bahwa Return on Asset (ROA), Earning Per Share (EPS), Return On Equity (ROE), dan Debt to EquityRatio (DER) tidak berpengaru signifikan terhdap return saham.
\end{abstract}

Kata Kunci : ROA, EPS, ROE, DER, Return Saham

Abstract-This study aims to determinethe effect of Return on Asset (ROA), Earning Per Share (EPS), Return On Equity (ROE), and Debt to EquityRatio (DER) on stock return in LQ-45 companies listed on the IDX in 2016-2017. The populations in this study amounted to 70 companies. The sampling technique uses purposive sampling technique, so the final sample obtained is 55 companies. The data used are secondary data obtained from the LQ-45 index financial statement data listed on the IDX. The research method used is the classic assumption test and multiple linear regression analysis with the help of SPSS application version 21. Besed on the results of the study showed that Return on Asset (ROA), Earning Per Share (EPS), Return On Equity (ROE), and Debt to EquityRatio (DER) has no significant impact on stock return.

Keywords : ROA, EPS, ROE, DER, Stock Return

\section{PENDAHULUAN}

Pasar modal merupakan suatu fasilitator kegiatan jual beli efek seperti obligasi, saham, reksadana, instrument derivatif maupun instrument lainnya yang diterbitkan oleh perusahaan yang telah terdaftar di dalam Bursa Efek Indonesia. bersadarkan UU Pasar Modal No.8 tahun 1995 berbunyi: "Kegiatan yang bersangkutan dengan penawaran umum dan perdagangan Efek, 
Perusahaan Publik yang berkaitan dengan efek yang diterbikannya, serta lembaga dan profesi uang berkaitan dengan Efek".

Perusahaan yang menjualkan efeknya di BEI dibedakan menjadi 9 kelompok, yaitu : pertanian; pertambangan; industri dasar \& kimia; industri manufaktur lainnya; industri barang konsumsi; properti, real estat dan kontruksi bangunan; infrastruktur, utilitas, \& transportasi; keuangan; perdagangan, jasa dan investasi. di BEI terdapat 45 perusahaan yang memenuhi kriteria tertentu disebut Indeks LQ-45. Adapun kriteria-kriteria Indeks LQ45 adalah sebagai berikut: termasuk dalam 60 perusahaan teratas dengan kapitalisasi maupun nilai transaksi tertinggi di pasar modal selama 1-2 bulan terakhir; minimal 3 bulan nama perusahaan telah tercatat di BEI; serta memiliki prospek pertumbuhan, kondisi keuangan dan nilai transaksi yang tinggi diantara perusahaan-perusahaan lain yang tercatat di BEI. Divisi penelitian dan pengembangan BEI melakukan penghitungan ulang setiap 6 bulan sekali untuk menentukan perusahaan yang mana yang akan ditetapkan sebagai Indeks LQ-45.

Akhir September 2018, indeks LQ-45 tercatat terkoreksi 12,34\%, turun lebih dalam dibanding Indeks Harga Saham Gabungan (IHSG) pada periode yang sama. Salah satu yang mendorong pelemahan indeks LQ-45 yaitu saham-saham dari sector konstruksi. Penyebabnya adalah kenaikan nilai utang yang tinggi karena mengerjakan proyek infrastruktur (Wareza, 2018).

Dalam tren terbaru, pasar saham telah menjadi stabil dan canggih dengan kemajuan teknologi dan pengenalan produk keuangan yang inovatif sebagai hasil dari proses rekayasa keuangan yang cepat. Kegiatan manipulasi telah meningkat dan ini telah meningkat secara signifikan risiko investasi di pasar saham (Kai \& Rahman, 2018).

Dari latar belakang yang telah diuraikan, maka penulis tertarik untuk melakuakan penelitian dengan judul "Faktor-Faktor yang Mempengaruhi Return Saham pada Perusahaan LQ-45 terdaftar di BEI Tahun 2016-2017'. Tujuan dari penelitian ini adalah untuk mengetahui dan menganalisis pengaruh antara ROA, EPS, ROE, dan DER terhadap return saham pada perusahaan LQ-45 yang terdaftar di BEI 2016-2017.

\section{METODE PENELITIAN}

Jenis penelitian yang digunakan merupakan penilitian kualitatif. Penelitian kualitatif adalah penelitian dengan menggunakan data berupa angka yang berasal dari perhitungan masing-masing atribut pengukuran variabel (Chandrarin, 2018).

Sedangkan jenis data yang digunakan adalah data sekunder, yaitu data yang berasal dari pihak 
atau lembaga yang telah menggunakan atau mempublikasikannya (Chandrarin, 2018). Dalam penelitian ini data yang digunakan berupa laporan keuangan yang telah dilaporkan atau dipublikasikan di website resmi Bursa Efek Indonesia.

Variabel yang digunakan untuk menguji antara variabel dependen yaitu return saham terhadap variabel independen yaitu ROA, EPS, ROE, dan DER.

1. Return Saham (Y)

Return saham adalah hasil yang diperoleh investor atas investasi yang ditanamkan.

$$
\text { Return }=\frac{\mathrm{P}_{1}-\mathrm{P}_{0}+\mathrm{d}_{1}}{\mathrm{P}_{0}}
$$

Keterangan :

$\mathrm{P}_{1}=$ Harga saham periode $\mathrm{t}$

$\mathrm{P}_{0}=$ Harga saham awal

$\mathrm{d}_{1}=$ Deviden kas

2. Return On Asset-ROA $\left(\mathrm{X}_{1}\right)$

Return On Asset (ROA) merupakan kemampuan perusahaan menghasilkan keuntungan dengan jumlah keseluruhan aktiva perusahaan (Ghonio, 2017).

$$
\text { ROA }=\frac{\begin{array}{c}
\text { Laba Bersih } \\
\text { Setelah Pajak }
\end{array}}{\text { Total Aktiva }}
$$

3. Earning Per Share-EPS $\left(\mathrm{X}_{2}\right)$

Earning Per Share (EPS) adalah keuntungan yang diberikan oleh perusahaan kepada para pemegang saham dari setiap lembar saham yang dimiliki (Sutapa, 2018).

$$
\text { EPS }=\frac{\begin{array}{c}
\text { Laba Bersih } \\
\text { Setelah pajak }
\end{array}}{\begin{array}{c}
\text { Jumlah Saham } \\
\text { Beredar }
\end{array}}
$$

4. Rerurn On Equity-ROE $\left(\mathrm{X}_{3}\right)$

Rerurn On Equity (ROE) merupakan kemampuan perusahaan dalam menghasilkan laba bersih bagi pemilik atau pemegang saham.

Laba Bersih

$$
\text { ROE }=\frac{\text { Setelah pajak }}{\text { Rata-Rata Ekuitas }}
$$

5. Debt to Equity Ratio-DER $\left(\mathrm{X}_{4}\right)$ Debt Earning Ratio (DER) merupakan suatu rasio keuangan yang menunjukkan proporsi relatif antara Ekuitas dan Hutang yang digunakan untuk membiayai aset perusahaan.

$$
\text { DER }=\frac{\text { Total Kewajiban }}{\text { Total Ekuitas }}
$$

Pengambilan data berupa dokumentasi dari laporan keuangan yang diakses melalui www.idx.co.id Data annual report perusahaan yang digunakan merupakan perusahaan yang tergabung dalam indeks LQ-45 terdaftar di Bursa Efek Indonesia (BEI) selama periode 2016-2017.

Populasi yang digunakan adalah perusahaan-perusahaan index LQ-45 yang terdaftar di Bursa Efek Indonesia (BEI) tahun 2016-2017 sebanyak 70 perusahaan. Setelah dilakukan outlier, terdapat 15 perusahaan di outlier, sisanya 55 peusahaan layak untuk dilakukan uji. Sedangkan sampel dicari meng- 
gunakan metode purposive sampling, yaitu termasuk salah satu metode penyempelan nonprobabilitas dengan berdasar pada kriteria tertentu. Kriteria yang ditetapkan untuk penelitian ini antara lain :

a. Perusahaan yang terdaftar di BEI dan berturut-turut terindex LQ-45 selama tahun 2016-2017.

b. Perusahaan yang melaporkan laporan keuangan konsolidasiannya tahun 2016-2017 ke website resmi BEI yaitu www.idx.co.id

c. Perusahana tidak mengundurkan diri dari Bursa Efek Indonesia selama tahun 2016-2017.

d. Laporan keuangan peusahaan disajikan dengan satuan mata uang rupiah.

Metode analisis data menggunakan analisis regresi linier berganda. Menurut Chandrarin (2018), analisis linier berganda yaitu analisis yang menguji hubungan pengaruh/dampak (kausalitas) satu variabel dependen dengan dua atau lebih variabel independen yang diformulasi dalam model statistik. Dalam pengolahan data peneliti menggunakan program IBM SPSS Statistics 21. Langkah-langkah yang dilakukan dalam analisis regresi linier berganda antara lain : (1) Uji statistik deskriptif; (2) Uji asumsi klasik : uji normalita, uji multikolinieritas, uji autokorelasi, \& uji heteroskedastisitas; (3) Analisis regresi linier berganda : uji regresi, uji koefisien regresi (uji F), uji hipotesis (uji t), \& uji koefisien determinasi $\left(\mathrm{R}^{2}\right)$.

\section{HASIL DAN PEMBAHASAN}

\section{Hasil Penelitian}

\section{Uji Statistik Deskriptif}

Dari hasil uji statistik deskriptif dapat dilihat ROA memiliki nilai min $=0,45, \max =16,48$, mean $=6,4691$ dan standar deviasi $=4,04098$. EPS memiliki nilai $\min =5,68, \max =$ 1984,64, mean $=378,3084$ dan standar deviasi $=400,16313$. ROE memiliki nilai $\min =0,74, \max =$ 29,16 , mean $=13,5095$ dan standar deviasi $=5,17158$. DER memiliki nilai $\min =0,15, \max =5,84$, mean $=$ 1,7298 dan standar deviasi $=$ 1,73725. Serta, Return Saham memiliki nilai $\min =-87,94, \max =$ 35,96 , mean $=-3,9051$ dan standar deviasi $=26,73932$.

Tabel 1. Hasil Statistik Deskriptif

\begin{tabular}{|c|c|c|c|c|c|}
\hline & N & Minim & Maxim & Mean & Std. Deviation \\
\hline ROA & 55 & .45 & 16.48 & 6.4691 & 4.04098 \\
EPS & 55 & 5.68 & 1984.64 & 378.3084 & 400.16313 \\
ROE & 55 & .74 & 29.16 & 13.5095 & 5.17158 \\
DER & 55 & .15 & 5.84 & 1.7298 & 1.73725 \\
\hline
\end{tabular}

Sumber: Diolah dari SPSS 21, 2020 


\section{Uji Asumsi Klasik}

\section{a. Uji Normalitas}

Dari hasil tabel di atas didapat bahwa nilai signifikansi sebesar 0,617. Standar normalitas data adalah
$>0,05$, karena nilai signifikansi lebih besar dari 0,05 maka dapat dikatakan bahwa data terdistribusi dengan normal.

Tabel 2. Hasil Uji Normalitas

\begin{tabular}{|l|c|c|c|}
\hline & $\begin{array}{c}\text { Kolmogorov- } \\
\text { Smirnov }\end{array}$ & $\begin{array}{c}\text { Asymp. } \\
\text { Sig. }\end{array}$ & Keterangan \\
\hline $\begin{array}{l}\text { Unstandardized } \\
\text { Residual }\end{array}$ & .756 & .617 & Normal \\
\hline
\end{tabular}

Sumber: Diolah dari SPSS 21, 2020

Tabel 3. Hasil Uji Multikolenieritas

\begin{tabular}{|c|c|c|c|}
\hline Variabel & Tolerance & VIF & Keterangan \\
\hline ROA & .114 & 8.792 & Bebas Multikolenieritas \\
EPS & .912 & 1.096 & Bebas Multikolenieritas \\
ROE & .187 & 5.358 & Bebas Multikolenieritas \\
DER & .203 & 4.919 & Bebas Multikolenieritas \\
\hline
\end{tabular}

Sumber: Diolah dari SPSS 21, 2020

\section{b. Uji Multikolenieritas}

Pengujian menggunakan Tolerance Value dan Variance Inflation Factor (VIF). Dapat dilihat dari tabel bahwa nilai tolerance dari semua variabel lebih dari 0,10 dan VIF kurang dari 10,0 maka dapat disimpulkan bahwa tidak terjadiultikolinieritas.

\section{c. Uji Autokorelasi}

Nilai DU dan DL diperoleh dari tabel statistik Durbin Watson. Dengan $\mathrm{n}=55$, dan $\mathrm{k}=4$ maka didapat nilai $\mathrm{DL}=1,14136$ dan $\mathrm{DU}$ $=1,7240$, jadi nilai 4 -DU $=2,276$ dan 4-DL $=2,5864$. Dari tabel diatas diperoleh nilai Durbin Watson sebesar 1,817. Nilai DW terletak antara DU dan 4-DU (1,7240 dan 2,276) maka dapat disimpulkan bahwa tidak ada autokorelasi pada model regresi.

Tabel 4. Hasil Uji Autokorelasi

\begin{tabular}{|c|c|c|c|c|}
\hline $\mathbf{R}$ & $\begin{array}{c}\mathbf{R} \\
\text { Square }\end{array}$ & $\begin{array}{c}\text { Adjusted R } \\
\text { Square }\end{array}$ & $\begin{array}{c}\text { Std. Error of } \\
\text { the Estimate }\end{array}$ & $\begin{array}{c}\text { Durbin- } \\
\text { Watson }\end{array}$ \\
\hline $.352^{\mathrm{a}}$ & .124 & .054 & 26.00578 & 1.817 \\
\hline
\end{tabular}

Sumber: Diolah dari SPSS 21, 2020 


\section{d. Uji Heteroskedastisitas}

Dapat diihat korelasi antara ROA, EPS, ROE, DPS dengan Unstandardized Residual memiliki nilai signifikan lebih dari 0,05 . Sehingga dapat disipulkan bila tidak terjadi heteroskedastisitas.

Tabel 5. Hasil Uji Heteroskedastisitas

\begin{tabular}{|c|c|c|c|}
\hline Variabel & Std. & $\begin{array}{c}\text { Unstandardized } \\
\text { Residual }\end{array}$ & Keterangan \\
\hline ROA & $>0,05$ & 0,832 & Bebas Heteroskedastisitas \\
EPS & $>0,05$ & 0,694 & Bebas Heteroskedastisitas \\
ROE & $>0,05$ & 0,735 & Bebas Heteroskedastisitas \\
DER & $>0,05$ & 0,977 & Bebas Heteroskedastisitas \\
\hline
\end{tabular}

Sumber: Diolah dari SPSS 21, 2020

\section{Analisis Regresi Linier} Berganda

a. Uji Regresi

$\mathrm{Y}=\mathrm{a}+\mathrm{b} 1 \mathrm{X} 1+\mathrm{b} 2 \mathrm{X} 2+\mathrm{b} 3 \mathrm{X} 3+\mathrm{b} 4 \mathrm{X} 4$ $+\mathrm{e}$

Keterangan:

$\mathrm{Y} \quad=$ Return Sahan

a $\quad$ Konstanta

$\mathrm{X} 1.1=\mathrm{ROA}$

$\mathrm{X} 1.2=\mathrm{EPS}$

$$
\begin{aligned}
& \mathrm{X} 1.3=\mathrm{ROE} \\
& \mathrm{X} 1.4=\mathrm{DER} \\
& \mathrm{b} 1, \ldots, \mathrm{b} 4=\text { Koefisien Regresi } \\
& \mathrm{e}
\end{aligned}
$$

Model regresi dalam penetian ini adalah sebagai berikut :

$$
\begin{aligned}
\mathrm{Y}^{\prime}=-25,074+(-0,377) \mathrm{ROA}+ \\
\\
0,016 \mathrm{EPS}+1,392 \mathrm{EPS}+(- \\
\\
0,776) \mathrm{DER}+\mathrm{e}
\end{aligned}
$$

Tabel 6. Hasil Uji Analisis Regresi Linier Berganda

\begin{tabular}{|c|c|c|}
\hline Variabel & B & Standart Error \\
\hline (Constant) & $-25,074$ & 11,115 \\
ROA & $-0,377$ & 2,597 \\
EPS & 0,016 & 0,009 \\
ROE & 1,392 & 1,584 \\
DER & $-0,776$ & 4,518 \\
\hline
\end{tabular}

Sumber: Diolah dari SPSS 21, 2020 


\section{b. Uji Kelayakan Modal (Uji F)}

Berdasarkan hasil uji $\mathrm{F}$ di atas menunjukkan nilai signifikan sebesar
0,000, nilai ini kurang dari 0,05 maka dapat disimpulkan bahwa model penelitian ini adalah fit.

Tabel 7. Hasil Uji F

\begin{tabular}{|c|l|l|l|l|l|l|}
\hline \multicolumn{2}{|l|}{ Model } & $\begin{array}{l}\text { Sum of } \\
\text { Squares }\end{array}$ & df & $\begin{array}{l}\text { Mean } \\
\text { Square }\end{array}$ & F & Sig. \\
\hline 1 & Regression & 4794,473 & 4 & 1198,618 & 1,772 &, $000^{\mathrm{b}}$ \\
& Residual & 33815,040 & 50 & 676,301 & & \\
& Total & 38609,513 & 54 & & & \\
\hline
\end{tabular}

Sumber: Diolah dari SPSS 21, 2020

\section{c. Uji Hipoesis (Uji t)}

Berdasarkan tabel di atas maka uji hipotesis (Uji t) sebagai berikut:

1) $\mathrm{H}_{1}$ : ROA berpengaruh signifikan terhadap Return Saham

Berdasarkan hasil pengujian uji $t$ diperoleh $t$ hitung untuk variabel ROA sebesar 0,057 berarti $\mathrm{t}$ hitung $<\mathrm{t}$ tabel $(-0,145<2,790)$ dan nilai signifikansi sebesar 0,885 yang artinya nilai signifikansi $>0,05$ maka ditarik kesimpulan bahwa ROA berpengaruh negatif dan tidak signifikan terhadap return saham.

2) $\mathrm{H}_{2}$ : EPS berpengaruh signifkan terhadap Return Saham

Berdasarkan hasil pengujian uji $t$ diperoleh $t$ hitung untuk variabel EPS sebesar 1,754 berarti t hitung $<\mathrm{t}$ tabel ( $1,754<2,790)$ dan nilai signifikansi sebesar 0,086 yang artinya nilai signifikansi >0,05 maka ditarik kesimpulan bahwa EPS tidak berpengaruh signifikan terhadap Return Saham.

3) $\mathrm{H}_{3}$ : ROE berpengaruh signifikan terhadap Return Saham

Berdasarkan hasil pengujian uji $t$ diperoleh $t$ hitung untuk variabel ROE sebesar 0,879 berarti $\mathrm{t}$ hitung $<\mathrm{t}$ tabel ( $0,879<2,790)$ dan nilai signifikansi sebesar 0,384 yang artinya nilai signifikansi >0,05 maka ditarik kesimpulan bahwa ROE tidak berpengaruh signifikan terhadap Return Saham.

4) $\mathrm{H}_{4}$ : DER berpengaruh signifikan terhadap Return Saham

Berdasarkan hasil pengujian uji $t$ diperoleh $t$ hitung untuk variabel DER sebesar 0,050 berarti $\mathrm{t}$ hitung $<\mathrm{t}$ tabel $(0,172<2,790)$ dan nilai 
signifikansi sebesar $\quad 0,864$ yang artinya nilai signifikansi $>0,05$ maka ditarik kesimpulan bahwa
DER tidak berpengaruh signifikan terhadap Return Saham.

Tabel 8. Hasil Uji t

\begin{tabular}{|c|c|c|c|c|c|}
\hline Variabel & $\mathbf{t}_{\text {tabel }}$ & Std. & T & Sig. & Keterangan \\
\hline ROA & 2,790 & $<0,05$ & $-0,145$ & 0,885 & Ditolak \\
EPS & 2,790 & $<0,05$ & 1,754 & 0,086 & Ditolak \\
ROE & 2,790 & $<0,05$ & 0,879 & 0,384 & Ditolak \\
DER & 2,790 & $<0,05$ & 0,172 & 0,864 & Ditolak \\
\hline
\end{tabular}

Sumber: Diolah dari SPSS 21, 2020

d. Uji Koefisien Deterinasi (Uji $\mathbf{R}^{\mathbf{2}}$ )

Dari tabel 9 di bawah dapat dilihat nilai koefisien determinasi (Adj $\mathrm{R}^{2}$ ) sebesar 0,054 yang berarti $5,4 \%$ variasi variabel dependen (return saham) dipengaruhi oleh variabe independen(ROA, EPS, ROE, DER). Sedangkan $94,6 \%$ variabel dependen dipengaruhi oleh faktor selain variabel yang diteiti.

Tabel 9. Hasil Uji $\mathbf{R}^{2}$

\begin{tabular}{|c|c|c|c|}
\hline $\mathbf{R}$ & $\begin{array}{c}\mathbf{R} \\
\text { Square }\end{array}$ & $\begin{array}{c}\text { Adjusted R } \\
\text { Square }\end{array}$ & $\begin{array}{c}\text { Std. Error of the } \\
\text { Estimate }\end{array}$ \\
\hline, $352^{\mathrm{a}}$ &, 124 &, 054 & 26,00578 \\
\hline
\end{tabular}

Sumber: Diolah dari SPSS 21, 2020

Pembahasan

1. Pengaruh antara ROA terhadap Return Saham

Berdasarkan hasil penelitian yang telah dilakukan ditemukan bahwa ROA tidak berpengaruh tehadap return saham. Dapat dilihat pada tabel 4.8 diperoleh $\mathrm{t}$ hitung sebesar $-0,057<\mathrm{t}$ tabel sebesar 2,790 dan nilai signifikansi sebesar $0,885>0,05$ maka ditarik kesimpulan bahwa
ROA tidak berpengaruh signifikan terhadap return saham. Hasil penelitian ini sejalan dengan penelitian yang dilakukan oleh (Mangantar, Mangantar \& Baramuli, 2020) yang mengatakan bahwa Return On Asset tidak berpengaruh signifikan terhadap return saham.

2. Pengaruh antara EPS terhadap Return Saham 
Berdasarkan hasil penelitian yang telah dilakukan ditemukan bahwa EPS tidak berpengaruh tehadap return saham. Dapat dilihat pada tabel 4.8 diperoleh $t$ hitung sebesar $1,754<\mathrm{t}$ tabel 2,790 dan nilai signifikansi sebesar 0,086 > 0,05 maka ditarik kesimpulan bahwa EPS tidak berpengaruh signifikan terhadap return saham. Hasil penelitian sejalan dengan penelitian yang telah dilakukan oleh (Rahmawati, Slamet, \& Maimunah, 2017), mengatakan bahwa secara parsial Earning Per Share (EPS) tidak berpengaruh pada return saham.

\section{Pengaruh antara ROE dan Return Saham}

Berdasarkan hasil penelitian yang telah dilakukan ditemukan bahwa ROE tidak berpengaruh tehadap return saham. Dapat dilihat pada tabel 4.8 diperoleh $\mathrm{t}$ hitung sebesar $0,879<\mathrm{t}$ tabel 2,790 dan nilai signifikansi sebesar 0,384 > 0,05 maka ditarik kesimpulan bahwa ROE tidak berpengaruh signifikan terhadap return saham. Hasil penelitian ini sejalan dengan penelitian yang telah dilakukan oleh (Susilowati \& Suharmanto, 2011), mengungkapkan bahwa Rerurn On Equity (ROE) tidak berpengaruh signifikan terhadap Return Saham.

\section{Pengaruh antara DER dan Return Saham}

Berdasarkan hasil penelitian yang telah dilakukan ditemukan bahwa DER tidak berpengaruh tehadap return saham. Dapat dilihat pada tabel 4.8 diperoleh $\mathrm{t}$ hitung sebesar $0,050<\mathrm{t}$ tabel 2,790 dan nilai signifikansi sebesar 0,864 >0,05 maka ditarik kesimpulan bahwa DER tidak berpengaruh signifikan terhadap return saham. Hasil penelitian ini sejalan dengan penelitian yang telah dilakukan oleh (Situmeang \& Dini, 2019), mengungkapkan bahwa Debt on Equity Ratio (DER) tidak berpengaruh positif dan tidak signifikan terhadap Return Saham.

\section{KESIMPULAN}

Penilitian ini bertujuan untuk mengukur apakah terdapat pengaruh antara Return on Asset (ROA), Earning Per Share (EPS), Return On Equity (ROE), dan Debt to EquityRatio (DER) terhadap Return Saham. Penelitian ini menggunakan 55 perusahaan indek LQ-45 yang terdaftar di BEI selama tahun 201762017. Digunakan teknik purposive sampling dengan kriteria dan ketentuan yang telah ditetapkan. Uji yang dilakukan dalam penelitian ini yaitu uji statistic deskriptif, uji asumsi klasik dan analisis regresi linier berganda. Berdasarkan hasil penelitian yang telah dilakukan mengenai pengaruh Return on Asset 
(ROA), Earning Per Share (EPS), Return On Equity (ROE), dan Debt to EquityRatio (DER) terhadap return saham, dapat disimpulkan beberapa hal sebagai berikut:

1. Return on Asset (ROA) tidak berpengaruh signifikan terhadap Return saham pada perusahaan LQ-45 yang terdaftar di BEI 20162017. Hasil penelitian ini sejalan dengan penelitian yang dilakukan oleh (Mangantar, Mangantar \& Baramuli, 2020) mengemukakan bahwa Return On Asset tidak berpengaruh signifikan terhadap return saham.

2. Earning Per Share (EPS) tidak berpengaruh signifikan terhadap Return saham pada perusahaan LQ-45 yang terdaftar di BEI 20162017. Hasil penelitian sejalan dengan penelitian yang telah dilakukan oleh (Rahmawati, Slamet, \& Maimunah, 2017) mengatakan bahwa secara parsial Earning Per Share (EPS) tidak berpengaruh pada return saham.

3. Return On Equity (ROE) tidak berpengaruh signifikan terhadap Return saham pada perusahaan LQ-45 yang terdaftar di BEI 20162017. Hasil penelitian ini sejalan dengan penelitian yang telah dilakukan oleh (Susilowati \& Suharmanto, 2011), mengungkapkan bahwa Rerurn On Equity (ROE) tidak berpengaruh signifikan terhadap Return Saham.

4. Debt to Equity Ratio (DER) tidak berpengaruh signifikan terhadap
Return saham pada perusahaan LQ-45 yang terdaftar di BEI 20162017. Hasil penelitian ini sejalan dengan penelitian yang telah dilakukan oleh (Situmeang \& Dini, 2019), mengungkapkan bahwa Debt on Equity Ratio (DER) tidak berpengaruh positif dan tidak signifikan terhadap Return Saham.

Adapun saran yang dapat diberikan oleh penulis antara lain :

1. Diharapkan penelitian yang akan datang menggunakan rasio-rasio keuangan yang lebih banyak dan mendetail agar menghasilkan pengaruh yang lebih baik.

2. Memperpanjang periode pengamatan serta menggunakan ataupun menambahkan perusahaan jenis lain.

3. Bagi penelitian yang akan datang dengan topic sejenis, disarankan untuk melakukan kajian lebih lanjut dengan menambah variablevariabel bebas lainnya, serta menggunakan penelitian terbaru untuk mendapatkan hasil penelitian yang lebih bias mendekati fenomena-fenomena sesungguhnya yang terdapat di pasar modal Indonesia.

\section{DAFTAR PUSTAKA}

Al-Salamat, W. A., \& Mustafa, H. H. (2016, September). The Impact of Capital Stucture on Stock Return: Empirical Evidence from Amman Stock Exchange. International 
Journal of Business and Social Science, 7(9), 183-196.

Basarda, R. F., Moeljadi, M., \& Indrawati, N. K. (2018, April). Macro and Micro Determinants of Stock Return Companies In LQ-45 Index. Jurnal Keuangan dan Perbankan, 22(2), 310-320. Retrieved from http://jurnal.unmer.ac.id/index .php/jkdp

Chandrarin, G. (2018). Metode Riset Akuntansi Pendekatan Kuantitatif. Jakarta: Salemba Empat.

Ghonio, M. G. (2017). Pengaruh Return on Asset (ROA) dan Return on Equity (ROE) Terhadap Harga Saham Pada Perusahaan Manufaktur yang Terdaftar di ASEAN Periode 2013-2015.

Gunai, G. G., \& Kesuma, K. W. (2015, Juni 29). Pengaruh ROA, DER, EPS Terhadap Perusahaan Food and Beverage BEI. E-Jurnal Manajemen, 4(6), 1636-1647. Retrieved from https://ojs.unud.ac.id/index.ph p/Manajemen/article/view/122 65

Kai, K. D., \& Abd-Rahman, I. B. (2018, Juli). The Impact of Financial Indicators towarda Stock Returns of Financie Companies Listed on Bursa Malaysia. International Journal of Academic Research in Accounting, Finance and Management Sciences, 8(3), 128-140. doi:10.6007/IJARAFMS/v8i3/4546
Mangantar, A. A., Mangantar, M., \& Baramuli, D. N. (n.d.). Pengaruh Return on Asset, Return on Equity dan Debt to Equity Ratio Terhadap Return Saham pada Subsektor Food and Beverage di Bursa Efek Indonesia.

Mustaf, S., Saeed, A., \& Zafar, A. (2017, October). The Effect of Financial Leverage dan Market Size on Stock Returns on the Karachi-Exchange: Evidence from Selected Stockin the Non-Financial sector in the Non-Financinal Selected Stock in The NonFinanial Sector of Pakistan. The International Journal of Business \& Management, 5(10), 246-252. Retrieved from https://www.theijbm.com/

Putriani, N. P., \& Sukartha, I. M. (2014). Pengaruh Arus Kas Bebas dan Laba Bersih pada Return Sahan Perusahaan LQ45. E-Jurnal Akuntansi Universitas Udayana, 6(3), 390-401.

Rahmawati, A., Slamet, B., \& Maimunah, S. (2017). Pengaruh Earning Per Share (EPS) Return On Equity (ROE) dan Debt To Equity Ratio (DER) Terhadap Return Saham Pada Perusahaan Food and Beverages yang Terdaftar di Bursa Efek Indonesia Periode 2011-2015. Jurnal Online Mahasiswa (JOM) Bidang Akuntansi, 2(2).

Siregar, M. (2007). Pengaruh Dividend Per Share dan Earning Per Share Terhadap Return Saham pada 
Perusahaan yang Terdaftar di Jakarta Islamic Index (JII). Retrieved from http://digilib.uinsuka.ac.id/id/eprint/18197

Situmeang, M. C., \& Dini, S. (2019, Agustus). Pengaruh Debt to Equity Ratio, Return on Asset, Current Ratio, dan Price to Earnings Ratio Terhadap Return Saham pada Indeks LQ45 Bursa Efek Indonesia Tahun 2014-2017. Jurnal Aksara Public, 3(3), 163-171. Retrieved from https://www.aksarapublic.com /index.php/home/article/view/ 289

Sudiyatno, B., \& Suharmanto, T. (2011). Kinerja Keuangan Konvensional, Economic Value Added, dan Return Saham. Jurnal Dinamika Manajemen, 153-161. Retrieved from https://journal.unnes.ac.id/nju/ index.php/jdm

Susilowati, Y., \& Tri, T. (2011, Mei). Reaksi Signal Rasio Profitabilitas dan Rasio Solvabilitas Terhadap Return Saham Perusahaan. Jurnal Dinamika Keuangan dan Perbankan, 3(1). Retrieved from

https://www.unisbank.ac.id/oj s/index.php/fe1/article/view/1 92

Sutapa, I. N. (2018, Januari). Pengaruh Rasio dan Kinerja Keuangan Terhadap Harga Saham Pada Indeks LQ45 di Bursa Efek Indonesia (BEI) Periode 2015-2016. Jurnal KRISNA: Kumpulan Riset
Akuntansi, $\quad 9(2), \quad$ 11-19. doi:10.22225/kr.9.2.467.11-19 Wareza, M. (2018, Oktober 01). CNBC Indonesia. Retrieved November 21, 2019, from https://www.cnbcindonesia.co $\mathrm{m} / \mathrm{market} / 20181001170403$ 17-35543/9-bulan-mencekamindeks-lq45-anjlok-1234 